\title{
Pengukuran Kadar Hormon Progesteron dan Deteksi Birahi pada Sapi Perah yang Disinkronisasi dengan CIDR (Controlled Internal Drug Release)
}

\author{
Measurement of Progesterone Hormone Levels and Heat Detection in Dairy Cows \\ Synchronized with CIDR (Controlled Internal Drug Release)
}

\author{
Oky Setyo Widodo ${ }^{1 *}$, Pudji Srianto ${ }^{2}$, Shelly Wulandari ${ }^{3}$ \\ ${ }^{1}$ Department of Animal Husbandry, ${ }^{2}$ Department of Veterinary Reproduction, \\ Faculty of Veterinary Medicine, Universitas Airlangga, \\ UNAIR C-Campus Mulyorejo, Surabaya, East Java, Indonesia, 60115 \\ ${ }^{3}$ Department of Health Science, Study Program of Animal Health, \\ Faculty of Vocational Education, Universitas Airlangga, \\ UNAIR B-Campus J1. Srikana 65, Surabaya, East Java, Indonesia, 60286 \\ *Corresponding author: oky.widodo@ fkh.unair.ac.id
}

\begin{abstract}
Abstrak
Deteksi birahi dan program perkawinan merupakan cara yang tepat untuk dapat mengoptimalkan performa reproduksi pada sapi perah. Rancangan penelitian yang dilakukan dalam penelitian ini adalah pretestpostest design. Terdiri dari empat macam perlakuan yaitu $\mathrm{P} 1 \mathrm{C} 1, \mathrm{P} 1 \mathrm{C} 2, \mathrm{P} 2 \mathrm{C} 1$, dan $\mathrm{P} 2 \mathrm{C} 2$, masing-masing perlakuan diulang sebanyak empat kali. Faktor yang diujikan adalah faktor P: usia korpus luteum 15 hari (P1) dan 10 hari (P2), faktor C: pencabutan atau pelepasan implan progesterone pada hari ke-9 (C1) dan pada hari ke13(C2). Hasil yang diperoleh dengan uji statistik menunjukkan bahwa tidak terdapat interaksi antara perbedaan usia korpus luteum dengan perbedaan waktu pencabutan atau pelepasan implan controlled internal drug release (CIDR) ( $>0.05$ ). Dari total sampel 16 ekor sapi perah, 13 sampel menunjukkan tanda birahi tiga hari setelah implan controlled internal drug release (CIDR) dilepaskan. Persentase total dari keseluruhan sampel yang menunjukkan tanda birahi adalah $81.25 \%$.
\end{abstract}

Kata kunci: deteksi birahi, sapi perah, corpus luteum, progesteron, controlled internal drug release (CIDR)

\begin{abstract}
Heat detection and mating program (breeding) is the right way to be able to optimize the optimum reproductive performance in dairy cows. The design of the research conducted in this study was a pretestpostest design. Consists of four kinds of treatment that P1C1, P1C2, P2C1, and P2C2, each treatment repeated four times. Factors tested are Factor P: the age of the corpus luteum is 15 days (P1) and 10 days (P2), Factor $C$ : remove the implant of progesterone on the 9 th day $(\mathrm{Cl})$ and on the 13th day $(\mathrm{C2})$. The results obtained by statistical tests indicate that there is no interaction between age differences corpus luteum with the time difference of remove controlled internal drug release (CIDR) ( $p>0.05)$. The total sample of 16 dairy cows, 13 samples showed signs of a heat on the three days after removed controlled internal drug release (CIDR). The total percentage of the overall sample showed signs of heat was $81.25 \%$.
\end{abstract}

Key words: heat detection, dairy cow, corpus luteum, progesterone, controlled internal drug release (CIDR)

Received: 21 April 2019

Revised: 26 Juni 2019

Accepted: 17 Juli 2019

\section{PENDAHULUAN}

Sapi perah merupakan ternak penghasil susu yang penting dalam industri peternakan di Indonesia. Salah satu masalah besar pengembangan usaha peternakan sapi perah di
Indonesia adalah rendahnya produktifitas dan efisiensi reproduksi. Penelitian dari (Bahonar et al., 2009) menjelaskan bahwa gangguan reproduksi berpengaruh terhadap fertilitas, kesehatan, dan produksi ternak. 
Penampilan reproduksi optimum pada sapi perah dapat tercapai jika jarak beranak (calving interval) optimum dengan kisaran 12 bulan (one year one calve). Deteksi birahi dan program pengawinan (breeding) yang tepat merupakan cara untuk dapat mengoptimalkan penampilan reproduksi optimum pada sapi perah.

Pengenalan teknologi reproduksi inseminasi buatan (IB) oleh pemerintah sejak tahun 1976 diharapkan dapat menjadi salah satu solusi peningkatan produktifitas dan efisiensi reproduksi sapi perah di Indonesia. Namun menurut Toelihere (1997), rendahnya keberhasilan IB dengan semen beku antara lain karena pelaksanaan IB pada waktu yang tidak tepat yang disebabkan karena kesulitan dalam mendeteksi estrus, akibatnya terjadi ketidak tepatan waktu inseminasi, dan akibatnya terjadi kegagalan fertilisasi.

Estrus yang terjadi tidak serentak dalam suatu kelompok ternak merupakan kendala utama dalam pelaksanaan IB. Upaya yang dilakukan untuk mengatasi kesulitan dalam deteksi birahi dikembangkan suatu teknologi yang dapat digunakan untuk mengendalikan birahi. Teknologi sinkronisasi estrus atau penyerentakan birahi dengan memanipulasi pola hormon reproduksinya.

Sinkronisasi estrus dapat dilakukan dengan pemberian sediaan progesteron. Sediaan implan progesteron yang banyak di gunakan untuk sapi perah adalah implan progesteron intra vagina controlled internal drug release (CIDR) yang mengandung 1,9 gram progesteron. Progesteron akan dilepas secara difusi dari karet silikon yang dibentuk menyerupai huruf "T" yang diaplikasikan secara intra vagina dengan menggunakan aplikator. Implan progesteron biasanya diinsersikan selama 7 sampai 10 hari. Selain dalam bentuk Controlled internal drug release (CIDR) progesteron dapat diberikan dalam bentuk progesterone releasing intravagina devices (PRID). Setelah pencabutan sediaan implan progesteron sapi akan mengalami estrus dan dapat dilakukan inseminasi.

Berdasarkan latar belakang permasalahan tersebut, deteksi birahi dan pemeriksaan hormon progesteron berguna untuk mengetahui siklus birahi secara umum dan ketepatan inseminasi dapat dilakukan, dengan demikian peningkatan produktifitas ternak dapat tercapai.

\section{METODE PENELITIAN}

Rancangan penelitian yang dilakukan dalam penelitian ini adalah rancangan acak lengkap (RAL) faktorial $2 \times 2$. Hewan yang dipergunakan dalam penelitian ini adalah 16 ekor sapi perah peranakan freisian holstein $(\mathrm{PFH})$ dengan keadaan tidak bunting, yaitu 8 ekor sapi perah dengan umur korpus luteum 15 hari (P1) dan 8 ekor sapi perah dengan umur korpus luteum 10 hari (P2). Pengelompokan hewan coba menggunakan sistem acak. Masing-masing perlakuan P1 dan P2 mendapat dua perlakuan, setiap perlakuan terdiri dari 4 ekor sapi perah yang dibedakan waktu pencabutan implan progesteron pada hari ke-9 (C1) dan hari ke-13 (C2). Terdiri dari empat macam perlakuan yaitu $\mathrm{P} 1 \mathrm{C} 1, \mathrm{P} 1 \mathrm{C} 2$, P2C1, dan $\mathrm{P} 2 \mathrm{C} 2$, masing-masing perlakuan di ulang sebanyak empat kali.

Data hasil pengukuran hormon progesteron yang diperoleh dianalisis dengan metode analysis of variant (Anova) dan untuk perbedaan rata-rata diantara perlakuan diuji dengan jarak berganda Duncan's 5\% (Duncan Multiple Range Test), bila hasilnya menunjukkan adanya perbedaan maka analisis statistik dilanjutkan dengan uji beda nyata terkecil (BNT). Analisis korelasi dilakukan berdasarkan perbedaan perlakuan dan waktu pelepasan implan progesteron terhadap kadar progesteron dalam darah. Sedangkan data pengamatan birahi ditampilkan dalam bentuk tabel dan disajikan secara diskriptif. Perangkat lunak yang digunakan untuk analisis data adalah Windows Statistical Program for Social science version 21 (SPSS).

Untuk mengetahui keadaan status pretest dilakukan teknik palpasi rektal dengan tujuan mengetahui hewan coba dalam keadaan bunting atau tidak. Riwayat rekording ternak juga diperlukan untuk mengetahui ternak dalam fase luteal, yaitu pada saat setelah ovulasi hingga 1517 hari. Penentuan waktu inseminasi atau deteksi birahi berdasarkan gejala klinis dan pengamatan 
di lapangan. Pakan hijauan yang diberikan adalah batang jagung (tebon), rumput gajah, dan rumput lapangan. Pakan konsentrat yang diberikan dalam penelitian ini adalah konsentrat buatan Koperasi Susu S.A.E Kecamatan Pujon Kabupaten Malang.

Implan progesteron yang digunakan dalam penelitian ini berupa controlled internal drug release (CIDR) EAZI-BREED CIDR ${ }^{\circledR}$ dengan kandungan 1.9 gram hormon progesteron. Alat aplikator CIDR dipergunakan untuk memasukkan implan progesterin kedalam vagina. Sebelum alat aplikator CIDR dipergunakan terlebih dahulu pada bagian permukaan luarnya di olesi dengan vaselin agar meminimalkan perlukaan pada dinding vagina dan memperlancar proses pemasangan implan progesteron.

Sampel darah yang didapat di tampung menggunakan tabung vacum tertutup dan dimasukkan kedalam termos yang berisi es dan dibawa ke laboratorium untuk di analisa. Pemeriksaan sampel untuk mengetahui kadar hormon progesteron dilakukan di Unit Endokrin Laboratorium Ilmu Kebidanan Departemen Reproduksi Fakultas Kedokteran Hewan Universitas Airlangga Surabaya.

Sampel darah diambil melalui vena jugularis pada setiap hewan coba menggunakan jarum venoject dan ditampung dengan vacum tube sebanyak $\pm 10 \mathrm{ml}$. Sampel darah yang sudah didapatkan disimpan dalam termos berpendingin yang selanjutnya dibawa ke laboratorium untuk dianalisa kadar hormon progesteron dalam darah. Pengambilan sampel dilakukan pada hari ke- $0,4,13,16,25$, dan 35 .

\section{HASIL DAN PEMBAHASAN}

\section{Kadar Hormon Progesteron}

Pemeriksaan kadar hormon dengan metode enzym linked immunosorbence assay (ELISA) competitive dilakukan pada seluruh sampel penelitian. Hasil yang didapat berdasarkan uji statistik menunjukkan bahwa tidak terdapat interaksi antara perbedaan umur korpus luteum dengan perbedaan waktu pencabutan CIDR ( $>0.05$ ). Hasil rata-rata (mean) dan standart deviasi (SD) kadar hormon progesteron antara interaksi umur korpus luteum dengan perbedaan waktu pencabutan CIDR disajikan pada Tabel 1 .

Rata-rata kadar hormon progesteron dari kombinasi perlakuan umur korpus luteum 15 hari dengan pencabutan CIDR pada hari ke-9 (P1C1) sebesar $1.53 \mathrm{ng} / \mathrm{ml}$, tidak berbeda nyata dengan kombinasi perlakuan umur korpus luteum 15 hari dengan pencabutan CIDR pada hari ke-13 (P1C2) sebesar $1.47 \mathrm{ng} / \mathrm{ml}(\mathrm{p}>0.05)$, kombinasi perlakuan umur korpus luteum 10 hari dengan pencabutan CIDR pada hari ke-9 (P2C1) sebesar $1.52 \mathrm{ng} / \mathrm{ml} \quad(\mathrm{p}>0.05)$, dan kombinasi perlakuan umur korpus luteum 10 hari dengan pencabutan CIDR pada hari ke-13 (P2C2) sebesar $1.54 \mathrm{ng} / \mathrm{ml}(\mathrm{p}>0.05)$.

Hasil yang didapat berdasarkan uji statistik menunjukkan bahwa tidak terdapat perbedaan yang nyata antara kombinasi perlakuan. Hal ini sesuai dengan pernyataan Kune (1998) bahwa tidak ada perbedaan yang berarti antara konsentrasi hormon progesteron sehari setelah implan dengan konsentrasinya setelah pencabutan implan. Implan progesteron selama 15 hari diperoleh konsentrasi hormon sebesar 0.3 $\mathrm{ng} / \mathrm{ml}$ pada saat implan, kemudian meningkat menjadi $8.6 \mathrm{ng} / \mathrm{ml}$ enam jam setelah implan, selanjutnya menurun menjadi $2.3 \mathrm{ng} / \mathrm{ml}$ pada saat pencabutan implan progesteron. Sementara apabila penggunaan implan dilakukan diawal siklus estrus (hari kedua atau ketiga), akan meningkatkan konsentrasi hormon progesteron dari $5.0 \mathrm{ng} / \mathrm{ml}$ setelah implan menjadi $6.5 \mathrm{ng} / \mathrm{ml}$ pada saat pencabutan implan (Peterson dan Henderson, 1990).

Mahaputra (1990) menyebutkan bahwa sapi perah yang mempunyai daur reproduksi normal, saat birahi kadar hormon progesteronnnya berada pada kadar basal, dan bila diikuti oleh ovulasi, maka kadar hormon progesteron serum darah akan meningkat pada hari ke-2 sampai hari ke-5 dan mencapai puncaknya pada hari ke-16 dari siklus birahinya.

Tidak adanya perbedaan yang berarti konsentrasi hormon progesteron pada saat implan dengan setelah pencabutan implan disebabkan karena pada saat implan progesteron dicabut, korpus luteum pada ternak tersebut 
Tabel 1. Rata-rata dan standart deviasi kadar hormon progesteron pada seluruh perlakuan (ng/ml)

\begin{tabular}{ccc}
\hline \multirow{2}{*}{$\begin{array}{c}\text { Umur Korpus } \\
\text { Luteum }\end{array}$} & \multicolumn{2}{c}{$\begin{array}{c}\text { Waktu Pencabutan Controlled internal drug release } \\
\text { (CIDR) }\end{array}$} \\
\cline { 2 - 3 } & $\mathbf{C 1}$ & $\mathbf{C 2}$ \\
\hline P1 & $1.53^{\mathrm{a}} \pm 1.30$ & $1.47^{\mathrm{a}} \pm 1.23$ \\
P2 & $1.52^{\mathrm{a}} \pm 0.99$ & $1.54^{\mathrm{a}} \pm 1.57$
\end{tabular}

Superskrip yang sama menunjukkan tidak ada perbedaan yang nyata antar perlakuan ( $p>0.05)$

Tabel 2. Data hasil pengamatan birahi pada ternak

\begin{tabular}{|c|c|c|c|c|c|}
\hline \multirow{2}{*}{ Perlakuan } & \multirow{2}{*}{ Ulangan } & \multicolumn{4}{|c|}{ Tanda Estrus pada Vulva } \\
\hline & & Kemerahan & Berlendir & Lembab & Hangat \\
\hline \multirow{4}{*}{$\mathrm{P} 1 \mathrm{C} 1$} & 1 & - & - & - & - \\
\hline & 2 & $\checkmark$ & $\checkmark$ & - & $\checkmark$ \\
\hline & 3 & $\checkmark$ & - & $\checkmark$ & $\checkmark$ \\
\hline & 4 & $\checkmark$ & - & - & $\checkmark$ \\
\hline \multirow{4}{*}{$\mathrm{P} 1 \mathrm{C} 2$} & 1 & $\checkmark$ & - & - & $\checkmark$ \\
\hline & 2 & $\checkmark$ & $\checkmark$ & - & $\checkmark$ \\
\hline & 3 & $\checkmark$ & $\checkmark$ & - & $\checkmark$ \\
\hline & 4 & $\checkmark$ & - & - & $\checkmark$ \\
\hline \multirow{4}{*}{$\mathrm{P} 2 \mathrm{C} 1$} & 1 & - & - & - & - \\
\hline & 2 & $\checkmark$ & - & - & $\checkmark$ \\
\hline & 3 & $\checkmark$ & $\checkmark$ & - & - \\
\hline & 4 & $\checkmark$ & - & $\checkmark$ & - \\
\hline \multirow{4}{*}{$\mathrm{P} 2 \mathrm{C} 2$} & 1 & - & - & - & - \\
\hline & 2 & $\checkmark$ & $\checkmark$ & - & $\checkmark$ \\
\hline & 3 & $\checkmark$ & - & - & $\checkmark$ \\
\hline & 4 & $\checkmark$ & $\checkmark$ & - & $\checkmark$ \\
\hline
\end{tabular}

Tanda $(\checkmark)$ pada tabel menunjukkan tanda estrus yang dapat diamati pada ternak

masih fungsional. Masalah ini dapat di tanggulangi dengan pemberian zat luteolitik. Cara lain yang dapat diharapkan untuk dapat meningkatkan efisiensi dan efektifitas penggunaan progesteron adalah dengan membatasi penggunaannya pada ternak yang hanya memiliki korpus luteum fungsional karena membutuhkan masa implan yang lebih pendek (Kune, 1998).

Kadar hormon progesteron berdasarkan perbedaan umur korpus luteum yang dipergunakan dalam penelitian ini yaitu umur korpus luteum 10 dan 15 hari tidak memberikan perbedaan yang nyata ketika dikombinasikan dengan perbedaan waktu pencabutan CIDR selama 9 dan 13 hari. Folikel dominan tidak mengalami perkembangan setelah insersi CIDR, namun pertumbuhan sangat pesat terjadi setelah pengambilan implan CIDR mencapai ukuran maksimum tiga hari kemudian pada saat estrus, kemudian menghilang karena terjadi ovulasi pada hari berikutnya. Korpus luteum dapat ditemui pada semua sapi saat insersi implan CIDR, kemudian berangsur-angsur mengalami regresi dan tidak lagi dapat diikuti setelah hari ke-6 insersi (Putro, 2013).

Menurut Putro (2013), pemberian implan progesteron CIDR ternyata menghambat perkembangan umur korpus luteum lebih lanjut. Hambatan perkembangan umur korpus luteum tersebut ada hubungannya dengan adanya peningkatan pasti hormon progesteron setelah insersi implan CIDR. Umur korpus luteum relatif tetap ukurannya sampai pengambilan implan 
CIDR, di mana terjadi penurunan tiba-tiba progesteron plasma, kemudian terjadilah perkembangan folikel ovulasi yang pesat diikuti oleh proses ovulasi.

Hasil ini memperkuat pendapat Garcia et al. (2004) dan Martinez et al. (2005), serta Salverson dan Perry (2007), bahwa pemberian progesteron eksogen akan meniru pekerjaan progesteron alami dari korpus luteum dan terjadilah umpan balik negatif pada hipotalamus yang berakibat adanya hambatan perkembangan folikel dan ovulasi. Pengambilan implan progesteron akan menyebabkan ditiadakannya umpan balik negatif tersebut dan terjadilah perkembangan cepat gelombang folikel baru, seleksi folikel dominan menjadi folikel ovulasi, sapi akan menunjukkan gejala estrus dan diikuti dengan proses ovulasi. Pembentukan korpus luteum ini distimulasi dengan hormon $\mathrm{LH}$ ditambah peran dari vascular endothelial growth factor (VEGF) sehingga terdapat vaskularisasi pada korpus luteum tersebut yang selanjutnya dapat membentuk hormon progesteron dengan memanfaatkan LDL dalam darah (Greenspan, 2004).

\section{Deteksi Birahi}

Data yang diperoleh didapat dari pengamatan birahi secara langsung (pengamatan visual). Pengamatan birahi dilakukan 2-3 hari setelah pencabutan CIDR. Tanda-tanda birahi yang muncul dari pengamatan secara visual dicatat dalam buku recording ternak (16 ekor sapi perah) kemudian diolah secara deskriptif. Hasil pengamatan birahi secara visual tersebut disajikan pada Tabel 2.

Berdasarkan Tabel 2, hampir seluruh sampel (16 ekor sapi perah) menunjukkan tanda-tanda birahi. Dari total keseluruhan sampel sebanyak 16 ekor sapi perah, 13 sampel menunjukkan tanda-tanda birahi yang nyata pada 2-3 hari setelah pencabutan CIDR. Terdapat tiga sampel penelitian yang tidak menunjukkan tanda-tanda birahi tiga hari setelah pencabutan CIDR yaitu satu sampel kombinasi perlakuan umur korpus luteum 15 hari dengan pencabutan CIDR pada hari ke-9 (P1C1), satu sampel kombinasi perlakuan umur korpus luteum 10 hari dengan pencabutan CIDR pada hari ke-9 (P2C1), dan satu sampel kombinasi perlakuan umur korpus luteum 10 hari dengan pencabutan CIDR pada hari ke-13 (P2C2). Jadi total presentase dari keseluruhan sampel yang menunjukkan tandatanda birahi sebesar $81.25 \%$.

Menurut Hafez and Hafez (2000), Estrus atau birahi adalah saat hewan betina mau menerima hewan jantan. Keadaan demikian ini ditimbulkan oleh tingginya kadar estrogen dalam darah. Selama estrus, korpus luteum mulai terbentuk saat ini kadar LH meningkat dan kadar FSH menurun. Setelah fase estrus berakhir maka akan timbul ovulasi. Hasil dari penelitian ini menunjukkan dari seluruh sampel 16 ekor sapi perah terdapat 13 sampel yang menunjukkan tanda-tanda birahi secara bersamaan setelah pencabutan CIDR atau sebanyak 81,25\% dari keseluruhan sampel.

Penggunaan CIDR untuk penyerentakan berahi telah banyak dilakukan baik pada sapi maupun ruminansia kecil. Progesteron akan dilepas secara difusi dari karet silikon yang dibentuk menyerupai huruf " $T$ " yang diaplikasikan secara intra vagina dengan menggunakan aplikator. Untuk sapi dara, penyerentakan berahi dilakukan dengan cara pemberian CIDR dan kapsul "CIDIROL" (mengandung $10 \mathrm{mg}$ oestradiol benzoat) selama 10 hari. Respon birahi yang dihasilkan mencapai lebih dari $90 \%$ dengan laju kebuntingan sebesar $65 \%$. Untuk sapi laktasi, CIDR ditambah kapsul "CIDIROL" diberikan selama tujuh hari. Deteksi berahi dilakukan dari hari ke-2 sampai hari ke-4 setelah CIDR dilepas. Respon birahi yang dihasilkan mencapai lebih dari $90 \%$ dengan laju kebuntingan antara 50-55\% (Interag, 1996). Berdasarkan pernyataan Interag (1996), pada penelitian ini respon birahi yang dihasilkan jauh lebih rendah yaitu sebesar $81.25 \%$.

Umumnya respon estrus yang diperlihatkan ternak selama proses pengamatan dalam penelitian ini (tiga hari) diduga dialami oleh ternak yang memiliki tiga gelombang folikel dengan lama setiap gelombang adalah tujuh hari. Sedangkan pada ternak yang memiliki dua gelombang folikel dengan waktu sembilan hari pada setiap gelombangnya, pengamatan birahi 
hasil dari sinkronisasi yang dibatasi selama tiga hari mungkin sulit teramati, karena kemungkinan folikel belum mencapai fase dominasi dan ovulasi. Apabila waktu yang diperlukan untuk mengamati tanda-tanda estrus pada penelitian ini dapat diperpanjang selama tujuh hari kemungkinan respon estrus yang diperlihatkan dapat melebihi $81.25 \%$.

\section{KESIMPULAN}

Perbedaan umur korpus luteum (10 dan 15 hari) yang dikombinasikan dengan perbedaan waktu pencabutan (9 dan 13 hari) implan progesteron CIDR tidak memberikan perbedaan yang nyata terhadap kadar progesteron dalam serum darah.

Penggunaan implan progesteron CIDR untuk sinkronisasi birahi yang dipasang pada saat fase luteal dapat menimbulkan birahi secara serentak.

\section{UCAPAN TERIMA KASIH}

Ucapan terima kasih penulis sampaikan kepada alm. Prof. Dr. Laba Maha Putra, drh., M.Sc. yang telah membantu dalam penelitian dan penyusunan laporan penelitian ini.

\section{DAFTAR PUSTAKA}

Bahonar, A.R., Azizzadeh, M., Stevenson, M.A., Vojgani, M. 2009. Factors affecting days open in Holstein dairy cattle in Khorasan Razavi Province, Iran; A Cox Proportional Hazard Model. J. Anim. Vet. Adv., 8, 747-754.

Garcia, F.E.O., Cordero, M.J.L., Hizarza, E.A., Peralta, O.J.G., Ortega, M.E., Cardenas, M., Gutierrez, C.G., Sanchez, T.E.M.T. 2004. Induction of a new follicular wave in Holstein heifers synchronized with norgestomet. Anim. Reprod. Sci., 80, 47-57.

Greenspan, F.S., Gardner, D.G. 2004. Basic and Clinical Endocrinology 7th edition. Large Medical Books/MC. Grow Hill. Med Publishing Dev. NY.
Hafez, E.S.E. 2000. Reproduction in Farm Animal. Fourth edition. Lea and Febiger. Philadelphia. USA.

Interag. 1996. Controled Breeding and Reproductive Management. Easi Breed CIDR. Hamilton New Zeland.

Kune, P. 1998. Sinkronisasi Estrus Memakai Progesteron, Prostaglandin P2 Alfa dan Esterogen dalam menimbulkan Estrus dan Konsepsi pada Sapi Potong. Tesis. Program Pascasarjana Institut Pertanian Bogor. Bogor.

Mahaputra L., Hariadi M., Hardjopranjoto S. 1990. Studies on The Reproductive Efficiency of Cattle Using Radioimmunoassay Techniques. Radioimmunoassay of Milk Progesterone to Monitor Reproductive Performance in Smallholder Dairy Herds in Indonesia. International. Atomic Energy Agency. Viena.

Martinez, M.F., Kastelic, J.P., Bo, G.A., Caccia, M., Mapletoft, R.J. 2005. Effect of oestradiol and some of its esters on gonadotrophin release and ovarian follicular dynamics in CIDR treated beef cattle. J. Anim. Sci., 86, 37-52.

Peterson, A.J., Henderson, H.V. 1990. Plasm Progesteron Concentration in Ovariectomised Dairy Cow Treated whith a CIDR-B Breeding Devices. J. Reprod. Fertil. Suppl., 43, 308.

Putro, P.P. 2013. Dinamika Folikel Ovulasi Setelah Perlakuan Sinkronisasi Estrus dengan Implan Progesteron Intravagina pada Sapi Perah. J. Sain Vet., 31(2), 128- 137.

Salverson, R., Perry, G. 2007. Understanding estrus synchronization of cattle. South Dakota State University-Cooperative Extension Service-USDA, p1-6. 
Toelihere, M.R. 1997. Animal reproduction in Indonesia State of Art. Makalah 4th
International Meeting on Biotechnology in Animal Reproduction. 6-9 August 1997. Bogor. 